\title{
ANALISIS SWOT PALANG MERAH INDONESIA (PMI) DALAM MELAKUKAN PENGURANGAN RISIKO BENCANA DI KOTA PADANG
}

\author{
Andre Lofika Pegi \\ Jurusan Ilmu Administrasi Publik, Fakultas Ilmu Sosial, Universitas Negeri Padang \\ E-mail: andrepegi06@gmail.com \\ Zikri Alhadi \\ Jurusan Ilmu Administrasi Publik, Fakultas Ilmu Sosial, Universitas Negeri Padang \\ E-mail: ianunpzikri@yahoo.co.id
}

\begin{abstract}
The purpose of this research is to find out and analyze the strengths, weaknesses, opportunities and threats encountered by the Indonesian Red Cross (PMI) in carrying out disaster risk reduction in the city of Padang. The method used in this research is descriptive qualitative method with data collection techniques through interviews and field documentation studies. Data were analyzed using SWOT analysis theory. This study shows the results that the strength is that, PMI has the strength of personnel who are reliable and specialists in their fields, PMI has a stable procedure and system, PMI already has its own law, namely Law no. 1 of 2018 and Government Regulation No. 7 of 2019. The disadvantage is that PMI is a voluntary organization so that in carrying out its duties PMI cannot be too forced and not too binding, PMI does not have a budget for risk reduction making it difficult to carry out operational activities, infrastructure and equipment at PMI is inadequate, the quantity of PMI personnel still not enough. The opportunity that is owned by PMI in carrying out disaster risk reduction is that PMI has the trust of the government, PMI's name is quite good in government and society. The threat is that community participation is still lacking when conducting disaster risk reduction socialization activities, PMI is turned into political land by certain individuals from external PMI, causing internal conflicts and affecting PMI performance.
\end{abstract}

Keywords: SWOT analysis, PMI, disaster risk reduction

How to Cite: Andre Lofika Pegi dan Zikri Alhadi. 2019. Analisis SWOT Palang Merah Indonesia (PMI) dalam Melakukan Pengurangan Risiko Bencana di Kota Padang. 3(2): pp. 14-30. DOI: https://doi.org/10.24036/jess/vol3-iss2

\section{Pendahuluan}

Kota Padang terletak di Pantai bagian Barat Pulau Sumatera. Kota Padang merupakan ibu kota Provinsi Sumatera Barat, salah satu kota yang memiliki tingkat kerawanan bencana yang cukup tinggi. Bencana menurut Undang-Undang No 24 Tahun 2007 
merupakan sesuatu peristiwa yang mengancam kehidupan masyarakat. Muis dan Khairil (2018) menjelaskan bencana adalah suatu peristiwa dikatakan bencana apabila peristiwa tersebut bersifat merusak dan menimbulkan kerugian pada masyarakat apabila suatu kejadian belum menimbulkan kerusakan dan kerugian maka belum bisa disebut bencana. Alhadi dan Siska (2014) dalam penelitiannya menyampaikan bahwa Kota Padang adalah salah satu wilayah atau kota yang paling pertama terkena gelombang bila diterjang bencana tsunami. Karena Kota Padang terletak di pantai barat pulau sumatera memiliki letak astronomis antara $100^{\circ} 05^{\prime} 05^{\prime}$ ' BT - 100'34'09" BT dan $00^{\circ} 44^{\prime} 00^{\prime \prime} \mathrm{LS}-01^{\circ} 08^{\prime} 35^{\prime}$ LS berbatasan langsung dengan laut luas yaitu Samudera Hindia.

Berdasarkan Kajian Risiko Bencana Kota Padang tahun 2014-2018 tingkat risiko bencana di Kota Padang di jelaskan dalam tabel sebagai berikut:

Tabel 1. Tingkat Risiko Bencana di Kota Padang

\begin{tabular}{clllllllll}
\hline \multirow{2}{*}{ No } & Jenis Bahaya & \multicolumn{2}{c}{ Bahaya } & \multicolumn{2}{c}{ Kerentanan } & \multicolumn{2}{c}{ Kapasitas } & \multicolumn{2}{c}{ Risiko } \\
\cline { 3 - 9 } & & Indeks & Tingkat & Indeks & Tingkat & Indeks & Tingkat & Indeks & Tingkat \\
\hline 1 & Banjir & 0,755 & Tinggi & 0,727 & Tinggi & 0,445 & Sedang & 0,670 & Tinggi \\
\hline 2 & Gempa Bumi & 0,537 & Sedang & 0,806 & Tinggi & 0,442 & Sedang & 0,622 & Sedang \\
\hline 3 & Tsunami & 0,729 & Tinggi & 0,735 & Tinggi & 0,409 & Sedang & 0,667 & Tinggi \\
\hline 4 & Tanah & 0,567 & Sedang & 0,556 & Sedang & 0,335 & Sedang & 0,590 & Sedang \\
& Longsor & & & & & & & & \\
\hline 5 & Kekeringan & 0,654 & Sedang & 0,785 & Tinggi & 0,470 & Sedang & 0,647 & Sedang \\
\hline 6 & Gelombang & 0,791 & Tinggi & 0,656 & Sedang & 0,342 & Sedang & 0,722 & Tinggi \\
& $\begin{array}{l}\text { Ekstrim dan } \\
\text { Abrasi }\end{array}$ & & & & & & & & \\
\hline 7 & $\begin{array}{l}\text { Cuaca } \\
\text { Ekstrim }\end{array}$ & 0,861 & Tinggi & 0,774 & Tinggi & 0,427 & Sedang & 0,732 & Tinggi \\
\hline 8 & $\begin{array}{l}\text { Kebakaran } \\
\text { Hutan dan }\end{array}$ & 0,516 & Sedang & 0,689 & Tinggi & 0,414 & Sedang & 0,582 & Sedang \\
& Lahan & & & & & & & & \\
\hline 9 & $\begin{array}{l}\text { Epidemi dan } \\
\text { Wabah }\end{array}$ & 0,333 & Rendah & 0,773 & Tinggi & 0,302 & Rendah & 0,564 & Sedang \\
& Penyakit & & & & & & & & \\
\hline 10 & $\begin{array}{l}\text { Gagal } \\
\text { Teknologi }\end{array}$ & 0,662 & Sedang & 0,664 & Sedang & 0,302 & Sedang & 0,742 & Sedang \\
\hline
\end{tabular}

Sumber : Kajian Risiko Bencana BPBD Kota Padang 2014-2018

Berdasarkan data table di atas dapat kita lihat peristiwa bencana di Kota Padang cukup tinggi Karena bencana merupakan sesuatu yang tidak bisa dicegah dan diduga kapan datangannya perlu adanya perhatian dari pemerintah dan masyarakat untuk menyusun tentang manajemen bencana manajemen bencana diartikan sebagai "suatu kegiatan yang terpadu, dinamis dan berkelanjutan, yang dilaksanakan semenjak sebelum kejadian bencana, pada saat atau sesaat setelah bencana hingga pasca bencana" Sadisun (2004). Menurut Alhadi (2014) manajemen bencana adalah 
keterpaduan antara seluruh tahapan bencana dari pra bencana, saat bencana, dan pasca bencana. Maka dapat disimpulkan manajemen bencana adalah serangkaian upaya yang bertahap dari prabencana, tanggap darurat hingga pasca bencana dengan tujuan untuk meminimalisir dampak dari bencana tersebut. Dalam tulisan ini yang menjadi fokus penelitian adalah untuk melakukan pengurangan resiko terhadap bencana. Salah satu strategi penting yang dilakukan sebelum terjadinya bencana adalah upaya pengurangan risiko. Pengurangan risiko bencana merupakan upaya yang dilakukan pada fase pra bencana atau pada saat sebelum terjadinya bencana. Pengurangan resiko bertujuan unuk mengurangi dampak kerusakan, kerugian dan korban jiwa yang disebabkan oleh bencana. Secara umum upaya pengurangan risiko disesuaikan dengan jenis dan karakteristik setiap potensi bahaya yang ada. Karena setiap daerah atau wilayah memiliki potensi bencana yang berbeda karena dipengaruhi oleh letek georafisnya masing-masing.

Beberapa langkah yang diambil dalam pengurangan risiko bencana secara garis besar terangkum dalam beberapa indikator yaitu; Pencegahan bahaya, Pengurangan Kerentanan, dan Peningkatan kapasitas. Untuk pelaksanaan pengurangan risiko bencana tersebut bukan hanya menjadi tanggung jawab dari pemrintah sendiri, seperti Badan Penanggulangan Bencana Daerah atau disingkat dengan BPBD, akan tetapi perlu adanya partisipasi dan keikutsertaan lembaga terkait serta peran lembaga non pemerintah dan masyarakat sehingga strategi dan tujuan dari penanggulangan bencana itu bisa terlaksana dengan baik sesuai dengan tujuan yang di inginkan. Salah satu stakeholder yang sangat berperan dalam pengurangan risiko bencana ini adalah Palang Merah Indonesia (PMI). PMI merupakan organisasi semi pemerintah karena sudah memiliki Undang-Undang sendiri yaitu Undang-Undang No 1 Tahun 2018 tentang Kepalangmerahan kemudian juga dijabarkan di dalam Peraturan Pemerintah No 7 Tahun 2019.

PMI merupakan organisasi yang bersifat independen bertujuan mengurangi beban penderitaan manusia disebabkan oleh bencana alam, bencana social, wabah penyakit dan sebagainya. PMI juga merupakan suatu organisasi yang berada dibawah perlindungan pemerintah, PMI juga melakukan tugas kemanusiaan yang tidak dilakukan oleh pemerintah. Organisasi PMI berada pada tingkat internasional, nasional, hingga ke provinsi dan sampai kepada kabupaten/kota hingga ketiap kecamatan. Dalam Undang-Undang No 1 Tahun 2018 pada Bab 5 pasal 22 di jelaskan tugas PMI yaitu; a) memberikan bantuan kepada korban koflik bersenjata, kerusuhan, dan gangguan keamanan lainnya; b) memberikan pelayanan darah sesuai dengan ketentuan yang diatur dalam peraturan perundang-undangan; c) melakukan pembinaan relawan; d) melaksanakan pendidikan dan pelatihan yang berkaitan dengan kepalangmerahan; e) menyebarluaskan informasi yang berkaitan dengan kegiatan kepalangmerahan; f) membantu dalam penanganan musibah dan/atau bencana di dalam dan luar negeri; g) membantu pemberian pelayanan kesehatan dan sosial; dan h) melaksanakan tugas kemanusiaan lainnya yang diberikan oleh 
pemerintah. pada penelitian ini akan membahas tentang tugas dan peranan PMI untuk membantu pemerintah dalam penanggulangan bencana yang fokusnya adalah pengurangan resiko akibat bencana karena pada kenyataannya bencana tidak dapat dicegah akan tetapi dapat diminimalisir dampak atau resiko akibat dari bencana tersebut . kemudian di jelaskan lebih lanjut dalam Peraturan Pmerintah No 7 Tahun 2019 pada bab 2 pasal 4 ayat 1 dijelaskan bagaimana penyelanggaraan kepalangmerahan pada penanggulangan bencana oleh pemerintah dilakukan untuk menjamin terselenggaranya pelaksanaan penanggulangan bencana secara terencana, terpadu, terkoordinasi, dan menyeluruh dalam rangka memberikan perlindungan kepada masyarakat dari ancaman, risiko, dan dampak bencana.

Dalam penyelenggaraan kepalangmerahan PMI melakukan penangulangan bencana pada setiap fase yaitu, fase pra bencana, tanggap darurat bencana dan pasca bencana. Pada kali ini yang menjadi pembahasan dalam penelitian ini adalah pengurangan risiko bencana oleh PMI di Kota Padang..

Permasalahan yang diahadapi oleh PMI dalam pengurangan resiko bencana adalah ketika pelaksanaan program sosialisasi pengurangan resiko bencana kurangnya respon dari masyarakat, kemudian jumlah personil yang siap turun kelapangan masih minim karena hanya bersifat sukarela . permasalahan lain yang dihadapi PMI adalah kurang koordinasi dan komunikasi dalam menyelenggarakan penanggulangan bencana, baik itu koordinasi sesama anggota dan juga dengan lembaga atau organisasi lain yang sama-sama memiliki tugas terhadap penanggulangan bencana. Selanjutnya yaitu permasalahan tidak adanya anggaran dana untuk melakukan penanggulangan bencana, permasalahan berikutnya peralatan dan perlengkapan yang masih sederhana dan juga sudah mulai dimakan usia sehingga banyak peralatan tersebut yang tidak layak pakai. Terakhir PMI Kota Padang masih kekurangan logistik untuk penanggulangan bencana tersebut. Berdasarkan pada peristiwa gempa yang terjadi beberapa tahun yang silam dan bencana banjir yang terjadi setiap tahunnya, PMI Kota Padang turun langsung memberikan bantuan kelapangan untuk menyalamatkan koban bencana yang di mulai dengan pertolongan pertama pada korban bencana, pengungsian sampai pada kondisi sudah dinilai aman.

Dari penjelasan tersebut terlihat bagaimana vitalnya peran PMI dalam penanggulangan bencana dan perlu diperhatikan efektivitas kinerja PMI dalam penanggulangan bencana dan disini berfokus kepada pengurangan risiko bencana oleh PMI Kota Padang. Dengan demikian menjadi permasalahan ini menjadi topik yang menarik untuk dibahas. Melihat Kota Padang merupakan salah satu kota yang memiliki potensi bencana yang sangat tinggi, maka pemerintah dan lembaga lainnya dituntut untuk meningkatkan kinerja dalam pengurangan risiko bencana seperti mitigasi dan kesiapsiagaan, salah satu lembaga tersebut adalah PMI Kota Padang. Oleh sebab itu perlu dilakukannya analisis tentang kinerja PMI dalam pengurangan risiko bencana. Agar yang menjadi tujuan dari penyelenggaraan manajemen bencana 
itu tercapai sebagaimana mestinya. Bertitik tolak dari latar belakang masalah di atas, maka penulis telah melakukan penelitian mengenai Analisis SWOT Palang Merah Indonesia (PMI) dalam Melakukan Pengurangan Resiko Bencna di Kota Padang dan penelitian ini juga bagian dari penelitian payung yang dilaksanakan oleh Zikri Alhadi (2018) dengan judul Model Kebijakan Pengutan Disaster Risk Governance dalam Pengurangan Resiko Bencana Tsunami di Kota Padng. Dalam penelitian ini yang menjadi fokus rumusan masalah adalah apa saja kekuatan, kelemahan, peluang, dan tantangan (SWOT) PMI dalam pegurangan risiko bencana di Kota Padang serta apa upaya PMI dalam mengatasi kelemahan serta ancaman dalam melakukan pengurangan resiko bencna di Kota Padang?

\section{Tinjauan Kepustakaan}

\section{Analisis SWOT}

Ananlisis SWOT pada dasarnya merupakan salah satu cara atau metode untuk mengetahui unsur internal dan eksternal yang ada di dalam sebuah lembaga atau organisasi yang sangat menentukan kemajuan dan pembangunan lembaga dan organisasi tersebut. Metode analisis SWOT bertujuan untuk mengevaluasi unsur internal dan ektsternal yang ada dalam sebuah organisasi dan kemudia dapat pula di tentukan strategi selanjutnya untuk meningktkan pembangunan dan kemajuan lemabaga atau organisasi yang sesuai dengan potensi yang dimiliki. Analisis SWOT ini di dasarkan pada kondisi umum institusi bersangkutan baik yang bersifat internal maupun eksternal guna untuk mencapai tujuan serta visi dan misi yang telah ditetapkan semula oleh para pemangku kepentingan.. Dalam memahami SWOT ada empat faktor yang digunakan untuk menganalisisnya yaitu, Strength (kekuatan), Weaknesses (kelemahan), Opportunities (peluang) dan Threat (ancaman).

\section{a. Kekuatan (Streangth)}

Pada dasarnya kekuatan adalah keunggulan atau potensi yang ada pada suatu daerah atau lembaga atau organisasi dan dilakukan perbandingan dengan daerah atau lembaga lainnya untuk melihat keunggulan yang ada tersebut. Kekuatan merupakan unsur positif yang terdapat pada internal suatu lembaga atau organisasi. Mengidentifikasi kekuatan biasanya dilihat dari pertama letak yang strategis, mudah di jangkau oleh alat transportasi, alat komunikasi yang memadai dan mendukung, adanya perlindungan hukum, sumber daya yang berkualitas serta peralatan dan prasarana yang lengkap dan juga memadai.

\section{b. Kelemahan (Weaknesess)}

Kelemahan yaitu kekurangan yang ada pada suatu daerah atau lembaga tertentu dan dilakukan pembandingan dengan daerah atau lembaga lainnya yang sejenis. Kelemahan tidak boleh dibirakan selama kelemahan tersebut dapat dilakukan 
perbaikan karena kelemahan akan mengahalangi suatu lembaga atau organisasi dalam mencapai tujuanya. Mengidentifikasi kelemahan sama juga dengan yang ada pada kekuatan akan tetapi kebalikan dari kekuatan tersebut. Seperti, letak yang tidak strategis jauh dari transportasi umum, tidak ada perlindungan hukum dari pemrintah, sumber daya manusia yang buruk, peralatan dan prasarana yang tidak lengkap dan juga anggaran dana yang tidak memadai.

\section{c. Peluang (opportunities)}

Opportunities dapat diartikan sebagai kesempatan dan kemungkinan yang tersedia dan dapat dimanfaatkan untuk mendorong proses pembangunan organisasi atau lembaga yang bersangkutan. Jika peluang dapat dimanfaatkan dengan baik maka akan mempermudah dalam pencapaian tujuan sehingga orgnisasi atau lembaga yang bersangkutan semakin baik lagi.

\section{d. Ancaman (threat)}

Ancaman diartikan sebagai suatu kondisi atau permasalahan yang datang dari luar dan menimbulkan kesulitan namun keberadaannya masih baru diprediksi belum tentu terjadi, ancaman dikahwatirkan akan menyebabkan kendala atau tantangan yang cukup serius bagi suatu daerah atau institusi tertentu Sjahrizal (2014). Jika ancaman yang ada tidak ditanggapi dengan serius maka takutnya akan mengganggu jalannya organisasi dan lembaga dalam menjalankan tugas dan mencapai tujuannya.

Keempat unsur SWOT dapat dikelompokkan atas dua, yaitu faktor dari dalam (internal) dan faktor dari luar (eksternal. Unsur kekuatan dan kelemahan pada dasarnya adalah merupakan faktor internal yang berasal dari dalam suatu atau lingkup tugas (TUPOKSI) institusi tertentu. sedangkan unsur peluang dan ancaman adalah merupakan faktor eksternal yang berasal dari luar atau ruang lingkup tugas tertentu tetapi berpengaruh terhadap masa depan lembaga atau organisasi dalam mencapai tujuan yang telah ditentukan semula.

Dari keempat faktor Analisis diatas merupakan berasal dari pada logika yang dapat memaksimalkan kekuatan dan peluang, yang secara bersamaan juga dapat meminimalkan kelemahan dan ancaman atau yang disebut dengan analisis situasi. Teori yang paling popular digunakan untuk analisis situasi adalah SWOT Rangkuty (2006). 
Tabel 2. Tabel Matriks SWOT

\begin{tabular}{ccc}
\hline & $\begin{array}{c}\text { Kekuatan } \\
(\text { Strengths-S })\end{array}$ & $\begin{array}{c}\text { Kelemahan } \\
(\text { Weaknesses-W })\end{array}$ \\
\hline $\begin{array}{c}\text { Peluang } \\
(\text { Opportunities-O) }\end{array}$ & Strategi SO & Strategi WO \\
\hline $\begin{array}{c}\text { Ancaman } \\
(\text { Threats-T })\end{array}$ & Strategi ST & Strategi WT \\
\hline
\end{tabular}

Sumber : Freddy Rangkuti (2006)

Berdasarkan tabel di atas dapat dijelaskan bahwa SO adalah memanfaatkan dengan maksimal seluruh kekuatan dengan memperhitungkan peluang yang dimiliki, WO memanfaatkan kelemahan dengan memperhatikan peluang, ST adalah memanfaatkan kekuatan dengan memperhatikan ancaman, dan WT memanfaatkan kelemahan dengan memperhatikan ancaman.

Hasil kajian akan memberikan informasi tentang faktor-faktor yang menjadi kekuatan dan kelemahan pada suatu lembaga atau organisasi, jika kekuatan yang lebih tinggi dapat memberi sinyal untuk ditindak lanjuti perencanaannya sehingga mempermudah dalam mencapai tujuan. Di sisi lain jika ancaman lebih kecil tentu juga menjadi isyarat untuk pengembangannya untuk perlu ditindaklanjuti agar ancaman tersebut bisa dihindari dan tidak menghalangi lembaga atau organisasi yang menjadi objek analisis dalm mewujudkan tujunnya, Arjana (2016).

\section{Pengurangan Resiko Benacana}

Pada dasarnya bencana tidak dapat di cegah dan diketahui kapan terjadinya namun upaya yang dapat dilakukan adalah meminimalisir dampak kerusakan dan kerugian yang disebabkan oleh bencana tersebut dengan melakukan usaha pengurangan resiko bencana. Pengurangan risiko bencana merupakan suatu upaya yang dilakukan ketika sebelum bencana terjadi atau disebut dengan fase prabencana. Pengurangan resiko bencana dapat dilakukan sesuai dengan keadaan daerah atau wilayah. Menurut Shandra (2013) paradigma bencana mengalami pergeseran dari tanggap darurat bencana ke kepada pengurangan risiko bencana. Pengurangan risiko pada dasarnya penekanan pada tahap pencegahan dan kesiapsiagaan. Maka perlu adanya analisis yang matang perlunya analisis mengenai ancaman, tingkat kerentanan, kemampuan masyarakat, serta ketersediaan sumber daya baik itu manusianya maupun persedian prasarana yang ada. Kemudian pelaksanaannya sesuai dengan ancaman bencana yang ada pada daerah tersebut. BPBD Kota Padang membagi strategi pengurangan risiko menjadi 4 macam yaitu, pencegahan. Kesiapsiagaan, mitigasi dan pengalihan resiko. 


\section{a. Pencegahan}

Pencegahan yaitu pengelolaan sumber bencana sehingga tidak menimbulkan risiko. Upaya pencegahan bahaya lebih kepada pengurangan tingkat risiko yang akan muncul dengan melakukan pengelolaan pada lokasi sumber bahaya. Dengan adanya perlakuan di sumber bahaya maka diharapkan kejadian bencana dapat dihilangkan. Berbagai upaya yang dilakukan perlu dikondisikan dengan jenis bahaya yang berpotensi terjadi. Bencana yang tidak bisa dicegah seperti gempa bumi dan cuaca ekstrim dapat dikembangkan upaya lebih kepada upaya pengurangan kerentanan.

\section{b. Kesiapsiagaan}

Kesiapsiagaan yaitu upaya penyelamatan diri (berfokus kepada komunitas) saat terjadi potensi bencana. Ketika terjadinya bencana maka masyarakat sudah mengetahui apa saja tindakan yang harus dilakukan, bisa dikatakan mereka sudah siap apabila bencana itu terjadi. Kesiapsiagaan didukung oleh sosialisai tentang kebencanaan dan simulasi mitigasi bencana yang dilaksanakan kepada masyarakat sehingga masyarakat terlatih dan siap apa bila terjadi bencana. Tujuannya yaitu untuk mengurangi dampak korban jiwa apa bila bencana itu terjadi.

\section{c. Mitigasi}

Mitigasi, yaitu membangun penghalang (buffer) secara struktural ataupun non struktural yang mampu melindungi komunitas dari bencana yang mungkin terjadi. Secara umum mitigasi dapat dikelompokkan ke dalam 2 macam yaitu mitigasi struktural dan mitigasi non struktural. Mitigasi struktural yaitu upaya pengurangan resiko bencana berhubungan dengan usaha-usaha pembangunan konstruksi fisik. Sementara mitigasi non struktural yaitu upaya pengurangan resiko bencana dengan cara perencanaan tata guna lahan yang disesuaikan dengan kerentanan wilayahnya dan memberlakukan peraturan (law enforcement) pembangunan.

Hermon (2012) mengatakan bahwa Penguatan kelembagaan juga diperlukan dalam tahap mitigasi, karena penguatan kelembagaan baik pemerintah, masyarakat maupun swasta merupakan faktor kunci suksesnya upaya mitigasi bencana. Perlu perhatian dan persiapan yang dilakukan bersama oleh pemerintah, masyarakat, dan swasta yang dilakukan dalam mitigasi bencana.

\section{d. Pengalihan Risiko}

Pengalihan risiko yaitu komunitas menghindar sebelum bencana terjadi, atau membiarkan pihak lain yang menanggung risikonya (asuransi). Penanggulangan bencana dan pengurangan risiko bencana merupakan tanggung jawab semua pihak. Perka BNPB Nomor 4 Tahun 2008 tentang pedoman penyusunan rencana penanggulangan bencana, menyatakan bahwa dalam melaksanakan penanggulangan 
becana di daerah akan memerlukan koordinasi dengan sektor. Adapun sektor yang dimaksud adalah sektor pemerintahan dan sektor non pemerintahan. Sektor pemerintahan terdiri dari sektor kesehatan, sektor sosial, sektor pekerjaan umum, sektor keuangan, sektor lingkungan hidup, dan lain-lainnya. Sedangkan sektor non pemerintahan terdiri dari masyarakat, swasta, lembaga non-pemerintahan, perguruan tinggi/lembaga penelitian, media dan lembaga internasional.

Lembaga-lembaga Non Pemerintah pada dasarnya memiliki fleksibilitas dan kemampuan yang memadai dalam upaya penanggulangan bencana. Dengan koordinasi yang baik, lembaga Non Pemerintah ini akan dapat memberikan kontribusi dalam upaya penanggulangan bencana mulai dari tahap sebelum, pada saat dan pasca bencana. Kerjasama antar pemerintah dan pihak-pihak non pemerintah merupakan suatu hal penting dalam upaya pengurangan risiko bencana. Pemerintah dapat membuka peluang sebesar-besarnya bagi perguruan tinggi, LSM, organisasi masyarakat, sektor swasta, dan pihak pihak lainnya untuk berpartisipasi aktif dalam pengurangan risiko bencana, termasuk dalam pengembangan Desa/Kelurahan Tangguh Bencana dan prakarsa-prakarsa serupa lainnya.

Pengurangan risiko merupakan kegiatan penanggulangan bencana pada fase prabencana. Pada pasal 7 Peraturan Pemerintah No 7 Tahun 2019 dijelaskan penyelenggaraan kepalangmerahan pada penanggulangan bencana oleh PMI pada prabencana adalah; a) penyusunan rencana kontingensi bencana; b) melakukan advokasi dan sosialisasi tentang kesiapsiagaan bencana; c) membantu pembangunan masyarakat menjadi tangguh bencana; d) penguatan pusat data dan informasi PMI.

\section{Metode Penelitian}

Artikel ini menggunakan pendekatan kulitatif dengan metode deskriptif. Penelitian dilakukan di Markas PMI Kota Padang, Kantor BPBD Kota Padang, anggota Komisi IV DPRD Kota Padang yang gawaiannya juga tentang penanggulanagan bencana kemudian dengan beberapa tokoh masyrakat yang ada di Kota Padang. Informan penelitian ditentukan dengan cara menggunakan teknik purposive sampling. Data yang dipakai dalam artikel ini adalah data primer dan data sekunder. Pengumpulan data dilakukan dengan cara wawancara dan studi dokumentasi. Uji keabsahan menggunakan triangulasi sumber. Sedangkan untuk teknik analisis data dilakukan dengan cara reduksi data, penyajian data, dan penarikan kesimpulan.

\section{Hasil dan Pembahasan}

\section{Hasil Penelitian}

\section{Analisis SWOT Palang Merah Indonesia (PMI) dalam Melakukan Pengurangan Resiko Bencana di Kota Padang}

Salusu (2015) menjelaskan Analisis SWOT merupakan suatu metode dalam penyusunan rencana stratejik yang digunakan untuk melihat dan mengetahui faktor 
utama yang mempengaruhi kegiatan di dalam suatu organisasi. Dalam penelitian ini, analisis SWOT digunakan untuk mengidentifikasi empat faktor utama yang mempengaruhi kinerja PMI dalam melakukan pengurangan risiko bencana di Kota Padang. Empat faktor utama tersebut meliputi :

\section{Kekuatan}

Kekuatan yaitu faktor internal dalam bentuk situasi dan kondisi serta kemampuan atau keunggulan yang dimiliki oleh organisasi, hal tersebut memungkinkan organisasi memiliki keuntungan stratejik dalam mencapai tujuannya. Dalam penelitian ini, kekuatan berarti kemampuan PMI Kota Padang yang bersifat positif dan berasal dari internal, yang memungkinkan PMI Kota Padang memiliki keuntungan stratejik dalam melakukan pengurangan resiko bencana dan juga untuk memudahkan dalam mencapai tujuan pengurangan resiko tersebut. Kekuatan yang dimiliki PMI yaitu pertama PMI memiliki kekuatan personil yang handal dan spesialis dibidangnya masing-masing. Kedua PMI memliki prosedur dan sistem yang sudah stabil, ketiga PMI juga sudah memliki UU sendiri yaitu UU No 1 Tahun 2018 dan Peraturan Pemerintah No 7 Tahun 2019. PMI juga sudah memiliki kelompok siaga bencana yang disebut Siaga Bencana Berbasis Masyarakat atau yang disingkat dengan SIBAT di 14 kelurahan di Kota Padang. SIBAT ini berfungsi sebagai perpanjangan tangan PMI dalam menyampaikan informasi kepada masyarakat tentang kebencanaan. Maka dari itu setelah di ketahuinya kekuatan yang dimiliki oleh PMI dapat di pertahankan dan dtingkatkan lagi sehingga mempermudah dalam pencapaian tujuan dalam melakukan pengurangan resiko bencana di Kota Padang yaitu mengurangi dampak, kerusakan, kerugian dan korban jiwa apabila terjadinya bencana. 
Tabel 3. Daftar Kelompok Siaga Bencana Berbasis Masyarakat (SIBAT)

\begin{tabular}{|c|c|c|}
\hline No & SIBAT/Kelurahan & Kecamatan \\
\hline 1. & SIBAT Kelurahan Baringin & Lubuk Kalangan \\
\hline 2. & SIBAT Kelurahan Indarung & Lubuk Kalangan \\
\hline 3. & $\begin{array}{l}\begin{array}{l}\text { SIBAT } \\
\text { Manis }\end{array} \\
\end{array}$ & Pauh \\
\hline 4. & Kelurahan Kalumbuk & Kuranji \\
\hline 5. & SIBAT Kelurahan Aia Pacah & Koto Tangah \\
\hline 6. & $\begin{array}{l}\begin{array}{l}\text { SIBAT } \\
\text { Minturun }\end{array} \\
\text { Kelurahan }\end{array}$ & Koto Tangah \\
\hline 7. & $\begin{array}{l}\text { SIBAT Kelurahan Padang } \\
\text { Sarai }\end{array}$ & Koto Tangah \\
\hline 8. & $\begin{array}{l}\text { SIBAT } \\
\text { Buaya }\end{array}$ & Koto Tangah \\
\hline 9. & $\begin{array}{l}\text { SIBAT Kelurahan Air Tawar } \\
\text { Barat }\end{array}$ & Padang Utara \\
\hline 10. & SIBAT Kelurahan Purus & Padang Barat \\
\hline 11. & SIBAT Mata Air & Padang Selatan \\
\hline 12. & $\begin{array}{l}\text { SIBAT Kelurahan Kampung } \\
\text { Pondok }\end{array}$ & Padang Barat \\
\hline 13. & $\begin{array}{lll}\text { SIBAT Kelurahan } & \text { Belakang } \\
\text { Pondok } & & \\
\end{array}$ & Padang Selatan \\
\hline 14. & SIBAT Kelurahan Cengkeh & Lubuk Bagalung \\
\hline
\end{tabular}

\section{Kelemahan}

Kelemahan adalah kekuarangan-kekurangan yang berasal dari internal PMI. apabila sauatu kekurangan tidak ditanggulangi dengan baik maka akan menghambat dalam pencapaian tujuan. Kelemahan-kelemahan yang dimiliki PMI sering berubah-ubah. Selanjutnya kelamahan yang dimiliki Pertama organisasi PMI merupakan organisasi semi pemerintah salah satu fungsinya yaitu membantu pemerintah dalam melakukan penanggulangan bencana dan bersifat sukarelawan sehingga dalam malaksanakan tugasnya PMI tidak bisa terlalu dipaksakan dan tidak terlalu mengikat. kedua PMI tidak memiliki anggaran untuk melakukan pengurangan risiko sehingga cukup sulit untuk melakukan kegiatan operasional. Ketiga, prasarana dan perlengkapan di PMI belum lengkap. Berdasrakan dari hasil penelitian manyatakan perlengkapan dan peralatan yang miliki oleh PMI belum memadai jika dibandingkan dengan wilayah dan jumlah penduduk Kota Padang. Keempat dari segi kuantitas personil PMI hanya bersifat relawan sehingga personil atau relawan masih kurang, terutama yang stanbey di markas. Kelima pimpinan pengurus PMI selalu dari pejabat sehingga membuat PMI kurang dinamis dan sulit berkembang karena dalam pelaksanaan tugas sudah terbiasa dengan pola birokrasi yang berbelit-belit dan rumit. Keenam PMI bersifat kaku karena terfokus pada protap sedangakan yang ditemukan berbeda dengan kenyataan dialapangan. 
Kemudian PMI sudah sangat jarang mengadakan pertemuan dengan SIBATSIBAT yang telah mereka bentuk di beberapa kelurahan, hanya mengandalkan grup WA untuk berkomunikasi dan itu kurang efektif dalam penyampaian informasi. Dalam menghadapi kelemahan tersebut perlau dicarikan solusi sehingga tidak menjadi penghambat dalam mencapai tujuan pengurangan resiko di Kota Padang.

Tabel 4. Daftar Pelengkapan Markas PMI Kota Padang

\begin{tabular}{clcc}
\hline No & \multicolumn{1}{c}{ Nama Barang } & Jumlah Barang & Keterangan \\
\hline 1. & Mobil Ambulance & 2 unit & \\
\hline 2. & Mobil Operasional & 3 unit & \\
\hline 3. & Perahu karet & 1 unit & \\
\hline 4. & Tenda Sanderbi & 2 unit & \\
\hline 5. & Radio HT & 6 buah & \\
\hline 6. & Radio Ric Posko & 3 buah & \\
\hline 7. & Radio Mobil & 3 buah \\
\hline 8. & Alat DU & 1 set \\
\hline 9. & Pelampung & 10 buah \\
\hline 10. & Tandu & 4 buah \\
\hline 11. & Tandu Spinal & 4 buah \\
\hline 12. & Tali Karamantel & 1 gulung \\
\hline 13. & Tas Pertolongan Pertama & 3 set \\
\hline 14 & Jas Hujan & 5 buah \\
\hline 15 & Computer & 3 unit \\
\hline 16 & Printer & 3 unit \\
\hline 17. & TV & 1 unit \\
\hline
\end{tabular}

\section{Peluang}

Peluang adalah faktor eksternal yang merupakan berbagai hal dan situasi yang menguntungkan bagi suatu organisasi serta kecenderungan kecenderungan yang merupakan salah satu sumber peluang. Dalam penelitian ini, peluang dilihat dari keuntungan yang mampu mendukung pencapaian tujuan pengurangan resiko bencana yang dilakukan di Kota Padang. Peluang juga diartikan sebagai kesempatan dan kemungkinan yang tersedia dan dapat dimanfaatkan untuk mendorong proses kinerja suatu organisasi. Peluang yang dimiliki PMI dalam melakukan pengurangan resiko bencana yaitu, dalam menjalankan tugas dan tanggungjawabnya PMI sudah bagus sehingga PMI mendapatkan kepercayaan dari pemerintah dan masyarakat, nama PMI cukup bagus di pemerintah dan masyarakat. Adapun ketika kegiatan sosialisasai yang diadakan oleh pemerintah, PMI selalu dilibatkan dan memiliki peranan penting dalam kegiatan tersebut.

\section{Ancaman}

Ancaman merupakan faktor eksternal yang merupakan faktor lingkungan yang tidak menguntungkan bagi PMI baik masa sekarang maupun masa yang akan datang. Dalam penelitian ini, ancaman dilihat dari kendala kendala yang timbul 
dari luar organisasi yang bersangkutan dalam melakukan pengurangan risiko bencana di Kota Padang. Ancaman yang dimiliki PMI yaitu: partisipasi masyarakat masih kurang ketika melakukan kegiatan sosialisasi tentang pengurangan resiko bencana, kemudian PMI juga dijadikan lahan politik oleh beberapa oknum tertentu dari pihak eksternal PMI sehingga akan menyebabkan konflik internal dan tentunya mempengaruhi kinerja PMI itu sendiri. Selanjutnya PMI merupakan organisasi yang berjenjang dimulai dari tingkat pusat hingga ke daerah kabupaten/kota akibatnya PMI yang lebih rendah akan bergantung kepada PMI tingkat atasnya sehingga kurangnya kemandirian.

\section{Pembahasan}

Dari hasil temuan penelitian di atas maka dapat kita lihat dalam tabel berikut ini kekuatan, kelemahan peluang dan ancaman yang dimiliki oleh PMI Kota Padang dalam melakukan pengurangan resiko bencana.

Tabel 5. Analisis SWOT PMI dalam Melakukan Pengurangan Resiko Bencana di Kota Padang

\begin{tabular}{|c|c|}
\hline Kekuataan /Strengths(S) & Kelemahan / Weaknesses (W) \\
\hline $\begin{array}{l}\text { 1. Memiliki personil yang handal dan } \\
\text { spesialis di bidangnya masing-masing. } \\
\text { 2. Memiliki sistem dan prosedur yang sudah } \\
\text { stabil. } \\
\text { 3. Memiliki UU No } 1 \text { Tahun } 2018 \text { dan PP No } \\
7 \text { Tahun } 2019 \text { tentang Penyelenggaraan } \\
\text { Kepalang Merahan. } \\
\text { 4. Memiliki Kelompok Siaga Bencana } \\
\text { Berbasis Masyarakat (SIBAT) di } 14 \\
\text { kelurahan di Kota Padang. }\end{array}$ & $\begin{array}{l}\text { 1. Bersifat kesukarelawanan sehingga tidak } \\
\text { bisa mengikat. } \\
\text { 2. Tidak memiliki anggaran dalam } \\
\text { melakukan pengurangan resiko bencana } \\
\text { 3. Sarana dan perlengkapan di PMI belum } \\
\text { memadai. } \\
\text { 4. Kuantitas dari anggota relawan yang } \\
\text { masih kurang. } \\
\text { 5. Kurangnya partisipasi dan kesadaran } \\
\text { masyarakat ketika kegiatan sosialisasi } \\
\text { pengurangan resiko bencana. } \\
\text { Ketua dari pengurus PMI berasal dari } \\
\text { pejabat sehingga kurang dinamis dan sulit } \\
\text { untuk berkembang, karena sudah terbiasa } \\
\text { dengan pola birokrasi yang berbelit-belit } \\
\text { dan rumit. } \\
\text { Bersifat kaku dalam pelaksanaan tugas } \\
\text { karena harus berdasarkan sesuai dengan } \\
\text { protap yang sudah ditentukan } \\
\text { 8. Pembentukan SIBAT tidak secara } \\
\text { berkelanjutan hanya sebagai bentuk } \\
\text { formalitas }\end{array}$ \\
\hline Peluang /Opportunities (O) & Ancaman / Threats (T) \\
\hline $\begin{array}{l}\text { 1. Mendapat kepercayaan dari pemerintah } \\
\text { dan masyarakat karena dalam menjalankan } \\
\text { tugas sudah dianggap bagus. } \\
\text { 2. Nama PMI cukup bagus di mata } \\
\text { pemerintah. }\end{array}$ & $\begin{array}{l}\text { 1. Organisasi PMI dijadikan sebagai lahan } \\
\text { politik oleh oknum yang berasal dari } \\
\text { eksternal PMI. } \\
\text { 2. PMI ketergantungan dan tidak ada } \\
\text { kemandirian }\end{array}$ \\
\hline
\end{tabular}


Dari matrik ditas dapat dicarikan solusi untuk menghadapi kendala yang ditemui PMI dalam melakukan pengurangan resiko bencana di Kota Padang. Strategi atau Upaya merupakan serangkaian usaha untuk meningkatkan mutu kinerja dan kulitas individu maupun organisasi dalam mencapai tujuan. Untuk memperbaiki dan meningkatkan efektivitas kinerja PMI dalam melakukan pengurangan risiko bencanan di Kota Padang maka perlu adanya uapaya sehingga tujuan dari pengurangan risiko itu dapat dicapai dengan baik.

\section{Tabel 6. Matriks Analisis SWOT Strategi PMI dalam Melakukan Pengurangan Resiko Bencana di Kota Padang}

\begin{tabular}{|c|c|c|}
\hline & $\begin{array}{l}\text { Kekuatan / Strengths } \\
\text { (S) }\end{array}$ & $\begin{array}{c}\text { Kelemahan / Weaknesses } \\
\text { (W) }\end{array}$ \\
\hline \multirow{6}{*}{$\begin{array}{c}\text { Peluang / } \\
\text { Opportunities } \\
\text { (O) }\end{array}$} & Strategi SO & Strategi WO \\
\hline & \multirow{2}{*}{$\begin{array}{l}\text { Revitalisasi sarana dan } \\
\text { prasarana. }\end{array}$} & Revitalisasi sarana dan prasarana \\
\hline & & \multirow{3}{*}{$\begin{array}{l}\text { Mengoptimalkan kegiatan sosialisai } \\
\text { Meningkatkan kesadaran masyarakat } \\
\text { Menambah jumlah anggota relawan }\end{array}$} \\
\hline & \multirow{2}{*}{$\begin{array}{l}\text { Meningkatkan kinerja } \\
\text { organisasi }\end{array}$} & \\
\hline & & \\
\hline & $\begin{array}{l}\text { Mengoptimalkan kegiatan } \\
\text { sosialisasi }\end{array}$ & $\begin{array}{l}\text { Pemeberian anggaran dana dari } \\
\text { pemerintah }\end{array}$ \\
\hline \multirow{4}{*}{$\begin{array}{l}\text { Ancaman / } \\
\text { Threats } \\
\text { (T) }\end{array}$} & Strategi ST & \\
\hline & \multirow[t]{2}{*}{ Mengoptimalkan potensi } & $\begin{array}{c}\text { Strategi WT } \\
\text { 1) }\end{array}$ \\
\hline & & 2) Pengawasan dan evaluasi kegiatan \\
\hline & $\begin{array}{l}\text { 2) Pengembangan kualitas } \\
\text { organisasi. }\end{array}$ & $\begin{array}{l}\text { 3) Meningkatkan kemandirian } \\
\text { organisasi }\end{array}$ \\
\hline
\end{tabular}

Berdasarkan matrik diatas dapat diambil disimpulkan bagaimana upaya yang dilakukan oleh PMI untuk mengatasi kendala dalam melakukan pengurangan risiko bencana di Kota Padang.

1. Open Recruitment relawan baru apabila para relawan sudah mulai kurang aktif di PMI, memberikan pelatihan terlebih dahulu kepada tim yang akan turun kelapangan untuk memberikan sosialisasi sehingga mereka lebih siap serta informasi yang disampaikan lebih padat dan berkualitas, menjaga komunikasi dengan stakeholder yang sama-sama bergerak di bidang penanggulangan bencana,

2. Melakukan pertemuan rutin dan berkala untuk menjaga komunikasi dan memudahkan koordinasi antar sesama stakeholder penanggulangan bencana, kemudian

3. Mengimbau kepada masyarakat agar selalu berpartisipasi ketika kegiatan sosialisasi ataupun simulasi yang diadakan oleh PMI maupun stakeholder penanggulangan bencana lainnya. 
4. Memberikan dana hibah yang memadai kepada PMI untuk melakukan kegiatan operasional pengurangan resiko bencana atau bisa dianggarkan dari ABPN atau APBD sehingga dalam melakukan kegiatan pengurangan resiko bencana dapat secara optimal.

5. Menambah jumlah anggota relawan serta meningkatkan kualitas dan kapabilitas anggota

6. Melengkapi serana dan peralatan PMI dalam melakukan pengurangan resiko

7. Menghimbau kepada masyarakat agar menikatkan kesadaran dan berpartisipasi aktif dalam program pengurangan resiko bencana di Kota Padang. Karena yang menjadi objek dari program ini adalah masyarakat,

\section{Penutup}

Faktor kekuatan, kelemahan, peluang, dan ancaman yang dimiliki PMI dalam melakukan pengurangan risiko bencana di Kota Padang dapat ditarik kesimpulan bahwa kekuatan PMI Kota Padang adalah pertama PMI memiliki kekuatan personil yang handal dan spesialis dibidangnya masing-masing. Kedua PMI memliki prosedur dan sistem yang sudah stabil, ketiga PMI juga sudah memliki UU sendiri yaitu UU No 1 Tahun 2018 dan Peraturan Pemerintah No 7 Tahun 2019.

Kemudian kelemahannya adalah Pertama organisasi PMI merupakan orgainsasi semi pemerintah salah satu fungsinya yaitu membantu pemerintah dalam melakukan penanggulangan bencana dan hanya bersifat sukarelawan sehingga dalam malaksanakan tugasnya PMI tidak bisa terlalu dipaksakan dan tidak terlalu mengikat. Kedua PMI tidak memiliki anggaran untuk melakukan pengurangan risiko sehingga cukup sulit untuk melakukan kegiatan operasional. Ketiga, prasarana dan perlengkapan di PMI belum lengkap. Keempat dari segi kuantitas personil PMI hanya bersifat relawan sehingga personil atau relawan masih kurang terutama yang standbye di markas. Kelima pimpinan pengurus PMI selalu dari pejabat sehingga membuat PMI kurang dinamis dan sulit berkembang karena dalam pelaksanaan tugas sudah terbiasa dengan pola birokrasi yang berbelit-belit dan cukup rumit. Keenam PMI bersifat kaku karena terfokus pada protap sedangakan kenyataan dialapangan cukup berbeda-beda. selanjutnya PMI sudah sangat jarang mengadakan pertemuan dengan SIBAT-SIBAT yang telah mereka bentuk dibeberapa kelurahan hanya mengandalkan grup WA untuk berkomunikasi dan itu kurang efektif dalam penyampaian informasi.

Selanjutnya peluang yang dimiliki PMI dalam melakukan pengurangan resiko bencana yaitu dalam menjalankan tugas dan tanggungjawabnya PMI sudah bagus sehingga PMI mendapatkan kepercayaan dari pemerintah, nama PMI cukup bagus di pemerintahan dan masyarakat. Adapun ketika kegiatan sosialisasai yang diadakan oleh pemerintah, PMI selalu dilibatkan dan memiliki peranan penting.

Terakhir yaitu ancamannya adalah partisipasi masyarakat masih kurang ketika melakukan kegiatan sosialisasi tentang pengurangan risiko bencana, kemudian PMI juga dijadikan lahan politik oleh beberapa oknum tertentu dari pihak eksternal PMI sehingga akan menyebabkan konflik internal dan tentunya mempengaruhi kinerja 
PMI itu sendiri selanjutnya PMI merupakan organisasi yang berjenjang dimulai dari tingkat pusat hingga ke daerah kabupaten/kota akibatnya PMI yang lebih rendah akan bergantung kepada PMI tingkat atasnya sehingga kurangnya kemandirian.

Upaya yang dilakukan oleh PMI dalam melakukan pengurangan risiko bencana di Kota Padang adalah melakukan open recruitment relawan baru apabila para relawan sudah mulai kurang aktif di PMI, memberikan pelatihan terlebih dahulu kepada tim yang akan turun kelapangan untuk memberikan sosialisasi sehingga mereka lebih siap serta informasi yang disampaikan lebih padat dan berkualitas, menjaga komunikasi dengan stakeholder yang sama-sama bergerak di bidang penanggulangan bencana, melakukan pertemuan rutin dan berkala untuk menjaga komunikasi dan memudahkan koordinasi antar sesama stakeholder penanggulangan bencana, kemudian mengimbau kepada masyarakat agar selalu berpartisipasi ketika kegaiatan sosialisasi ataupun simulasi yang diadakan oleh PMI maupun stakeholder penanggulangan bencana lainnya.

\section{DAFTAR KEPUSTAKAAN}

\section{Buku}

Hermon, Dedi. 2012. Mitigasi Bencana Hidrometeorologi, Banjir, Longsor, Ekologi, Degradasi Lahan, Putingbeliung, Kekeringan. Padang: UNP Press

Maleong, Lexy J. 2013. Metode Penelitian Kualitatif. Bandung: Remaja Rosdakarya Offset.

Rangkuty, Freddy.2006. Analisis SWOT Teknik pembelah kasus bisnis. Jakarta: PT. Gramedia Pustaka Umum.

Salusu. (2015). Pengambilan Keputusan Stratejik untuk Organisasi Publik dan Organisasi Non Profit. Jakarta: Garuda.

Sjafrizal. 2014. Perencanaan Pembangunan Daerah Era Otonomi. Bandung: Rajawali Press

\section{Jurnal}

Alhadi, Zikri. Kesiapan Jalur Dan Lokasi Evakuasi Publik Menghadapi Resiko Bencana Gempa Dan Tsunami Di Kota Padang (Studi Manajemen Bencana). Humanus Vol. XIII No.1 Th. 2014.

Alhadi, Zikri dan Siska Sasmita. Kesiapsiagaan Masyarakat Kota Padang Dalam Menghadapi Resiko Bencana Gempa Dan Tsunami Berbasis Kearifan Lokal (Studi Kesiapsiagaan Terhadap Resiko Bencana). Humanus Vol. Xiii No.2 Th. 2014

Muis, Ichwan dan kharil Anwar. Model kesiap siagaan Masyarakat dalam Pengurangan RIsiko Bencana Tanah Longsor di Desa Tugunukti Kecamatan Cisorua Kabupaten Bandung Barat. Volume 3, Issue 4 Th 2018 
Wandasari, S. L. (2013). Singkronisasi Peraturan Perundang-undangan dalam Mewujudkan Pengurangan Resiko Bencana. Unnes Law Journal 2 (2), 137-150.

\section{Sumber Referensi dari Undang-Undang dan Dokumen}

Kajian Risiko Bencana BPBD Kota Padang 2014-2018.

Undang-Undang Republik Indonesia Nomor 1 Tahun 2018 Tentang Kepalang Merahan.

Peraturan-Pemerintah Republik Indonesia No 7 Tahun 2019 Tentang Peraturan Pelaksanaan Undang-Undang Nomor 1 Tahun 2018 Tentang KepalangMerahan. 